\title{
Long term climatic trends in Chile and effects on soil moisture and temperature regimes
}

Neal Stolpe ${ }^{1 *}$, and Pablo Undurraga ${ }^{2}$

\section{ABSTRACT}

Climate change could potentially affect agricultural and forest production in Chile through changes in soil moisture and temperature regimes. In Soil Taxonomy the Soil Moisture Regime (SMR) is used to classify soils at the Suborder, Great Group and Subgroup levels, whereas Soil Temperature Regime (STR) is mainly used at the Family level. Both SMR and STR can be calculated using climatic data input to the Newhall model. Therefore, the objective of this research was to test the hypothesis that long term climate change has already affected the SMR and STR in different locations of the country. Historical values (1912-2015) of monthly precipitation and temperature were input to the model, with the available soil water set to $180 \mathrm{~mm}$, and the offset of air to soil temperature set to $2{ }^{\circ} \mathrm{C}$. The climatic records indicated a general trend of less precipitation in central and south central Chile whereby the SMR changed in Concepción from UsticUdic Tropustic to Ustic-Typic Tropustic; in Puerto Montt from Perudic to Udic-Typic Udic; and in Punta Arenas from Aridic-Typic Aridic to Xeric-Typic Xeric. In general, the recent period had more frequent extreme dry years. There was also a general tendency for slightly cooler temperatures mainly along the coast, and warming in Santiago, but the dominant STRs did not change between periods. Additionally, in south central Chile there was a decrease of annual moist days when the soil temperature is $\geq 5^{\circ} \mathrm{C}$, which suggests that in some areas soil temperature and moisture conditions have become somewhat more limiting over time, and, if continued, will likely result in a southerly expansion of the Xeric SMR, and increased need for supplemental irrigation of crops.

Key words: Soil taxonomy, soil classification, Newhall model.

${ }^{1}$ Universidad de Concepción, Facultad de Agronomía, Avenida Vicente Méndez 595, Chillán, Chile.

"Corresponding author (nstolpe@udec.cl).

${ }^{2}$ Instituto de Investigaciones Agropecuarias, INIA Quilamapu, Avenida Vicente Méndez 515, Chillán, Chile.

Received: 30 June 2016.

Accepted: 13 October 2016.

doi:10.4067/S0718-58392016000400013

\section{INTRODUCTION}

Long term climate change has the potential to affect agricultural and forestry production through alterations in the soil environment that may include organic matter content and quality, as well as the soil temperature regime and soil hydrology, principally due to shifts in rainfall zones and patterns of potential evapotranspiration (Clements et al., 2011). Accordingly, the recent Intergovernmental Panel on Climate Change (IPCC) report stated that increased climate variability and extreme events during 1950-2008 have severely affected the South American region, whereby subtropical South America has had general increases in temperature extremes and southeastern South America has experienced more frequent heavy rainfalls which have caused occasional landslides and flash floods. In Chile, there has been decreasing rainfall in the south-central region, with localized cooling along the coast due to increased upswelling of coastal waters and more intense trade winds (Magrin et al., 2014), but the cooler coastal temperatures may also be influenced by increasing atmospheric contamination of $\mathrm{SO}_{2}$ (MenaCarrasco et al., 2014). Similarly, during the period between 1979 and 2006 in central and northern Chile $\left(17^{\circ}-37^{\circ} \mathrm{S}\right.$ lat) there was a general surface cooling along the coast $\left(-0.2^{\circ} \mathrm{C}\right.$ decade $\left.^{-1}\right)$ that is probably related to larger scale patterns of La Niña, which strongly contrasted with a general warming $\left(+0.25^{\circ} \mathrm{C}\right.$ decade $\left.^{-1}\right)$ just $100-200$ $\mathrm{km}$ further inland (Falvey and Garreaud, 2009).

During the Twentieth Century in south central Chile, the overall decrease in precipitation has been approximately 30\%, which occurred principally in semi-arid areas that have intensive anthropogenic pressures on the land. Climatic tendencies and oscillations have been accentuated, in part, by oceanic temperatures and intense events of La Niña that took place in 1988-1989 and 1995-1996 that intensified droughts in central Chile (Minetti et al., 2003; Dore, 2005; Haylock et al., 2006). Projections of climate change in Chile, whether natural or anthropogenic in origin, suggest that significant changes in precipitation and soil moisture regimes will take place in some regions, as affected by a continued decrease of precipitation along the coast and an increase of precipitation on the southern tip of the country (Vera et al., 2006; Seneviratne et al., 2010; Quintana and Aceituno, 2012). Additionally, based on projected $\mathrm{CO}_{2}$ emission scenarios, by the end of the $21^{\text {st }}$ century the Mediterranean climate zone in Chile is expected to increase between $129 \%-153 \%$ of its current size. Such changes in climate would probably diminish the adaptation potential of native biota (Klausmeyer and Shaw, 2009), and lower the biodiversity of soil microorganisms (Carey, 2016). Additionally, alterations in the temperature and precipitation 
patterns can affect the net balance between mineralization or accumulation of organic matter that is stored in soils which, in turn, may result in increased release of $\mathrm{CO}_{2}$ to the atmosphere or more sequestration of atmospheric $\mathrm{C}$ in soils, respectively, which could amplify the change in climatic conditions (Davidson and Janssens. 2006).

In general, productive soils of central and south central Chile are used for cereal-pasture rotations, orchards and vineyards, while forest plantations are typically established in cooler and rainier zones further south, or in mountainous terrain. The variability of climate from one year to the next has already produced some uncertainty in the expected annual production of agricultural-forestry products in Chile, which are important sectors of the economy that had a total export value in 2014 of US\$15 889529 (Yañez and Cohen, 2015). Climate change in central Chile could potentially alter precipitation and temperature regimes that would diminish the yields of wheat, fruits, and forest plantations in some areas, and eventually force adjustments in planting dates and geographic shifts in agricultural and forestry activities (Seo and Mendelsohn, 2008; Magrin et al., 2014). The establishment and management of vineyards would also be affected because they are highly dependent upon favorable temperature regimes and adequate supplies of freshwater for irrigation (Hannah et al., 2013). Consequently, the Chilean government through the Ministries of Agriculture and Natural Environment has created a National Plan for adaptation of the agriculture and forestry sectors to climate change (MMA, 2013).

Soil Taxonomy (Soil Survey Staff, 2014) is the principal system for soil classification in Chile and has been used in official governmental documents with detailed soil descriptions and data that accompany the soil maps for different regions of the country (CIREN, 1996a; 1996b; 1997a; 1997b; 1999; 2002; 2003; 2005a; 2005b; 2007). One of the significant aspects of Soil Taxonomy is that it includes characterizations of both soil moisture and soil temperature regimes, which highlights a conceptual understanding that every soil is physically fixed to a location. For a soil to be sustainably used at a given location, the appropriate management practices must address not only the physical and chemical properties of the soil, but also the prevalent weather occurring in the area (Buol et al., 2011). In Soil Taxonomy, compared to other taxonomic systems, climate plays a bigger role to classify a soil than the other factors of soil formation (i.e. parent material, topography, vegetation and time) (Bockheim et al., 2014). Soil Moisture Regimes (SMR) are used to classify soils at the Suborder, Great Group and Subgroup levels of Soil Taxonomy, whereas Soil Temperature Regimes (STR) are most commonly used at the Family level (Soil Survey Staff, 2014). In Chile, as well as in other countries, soils have been mapped and classified in order to better utilize the soil resource for agricultural and forestry production, based upon morphological, physical and chemical properties of the soils, as well as normal climatic conditions that influence temperature and moisture at defined depths, or control sections, in soil pedons.
A normal year for precipitation, is defined in Soil Taxonomy as one that has total rainfall within \pm one standard deviation of the long-term (30 yr or more) mean annual precipitation. Additionally, the mean monthly precipitation during a normal year must be within one standard deviation of the mean monthly precipitation for 8 of the 12-mo. Generally, normal years can be calculated from the mean annual precipitation. The upper boundary of the soil moisture control section (SMCS) is the depth to which a dry soil (> $1500 \mathrm{kPa}$ tension) will be moistened by $2.5 \mathrm{~cm}$ of water within $24 \mathrm{~h}$. The lower boundary is the depth moistened by $7.5 \mathrm{~cm}$ within $48 \mathrm{~h}$. Therefore, based on the defined boundaries, the SMCS extends approximately between 10 and $30 \mathrm{~cm}$ depths in silty and clayey soils, 20 and $60 \mathrm{~cm}$ in loamy soils, and 30 and $90 \mathrm{~cm}$ in sandy soils (Buol et al., 2011). In practice, however, the determination of the predominant SMR in an area is primarily based on the estimation of the number and seasonality of dry days in a SMCS that are calculated using meteorological data (Buol et al., 2011; Winzeler et al., 2013). In contrast to the SMCS, the depth of the control section for STR is generally set at $50 \mathrm{~cm}$ below the soil surface. In practice, soil temperature is seldom measured directly but estimated, depending on the region, by adding $1-2{ }^{\circ} \mathrm{C}$ to the atmospheric temperature when actual soil measurements are not available (Buol et al., 2011).

In Chile, the mean annual precipitation generally increases, and mean annual temperature decreases, with increasing southerly latitude. The general tendencies, however, are modified by other factors that include topography, elevation and distance from the ocean (DMC, 2016). Consequently, most of the SMR and STR that are used in Soil Taxonomy are also found in Chile. For example, the predominant SMR in northern Chile is Aridic, which transitions to Xeric in Central Chile, to Ustic, Udic and finally Perudic with increasing southerly latitudes on the coast (Figure 1). The predominant STR in the north is Thermic with Isothermic on the coast which transitions to Mesic and Isomesic (coast) in central Chile, and Frigid in the extreme southern regions. The higher elevations of the Andes Mountains usually have Cryic STR (Figure 1) (Van Wambeke and Luzio, 1981; Luzio et al., 2010; NRCS, 2016a).

The Newhall model (Newhall and Berdanier, 1996) was specifically developed to determine the SMR of soils through available climatic data (Buol et al., 2011) and has been widely used to calculate and map regimes of soil moisture and temperature in the USA (Bonfante et al., 2011; Winzeler et al., 2013; NRCS, 2016a) and for diverse parts of the world including South America and Chile (Van Wambecke, 1981; Van Wambecke and Luzio, 1981). In the model, relatively simple water balance equations are employed to calculate SMRs for soils not strongly affected by endosaturation, whereas STRs are determined using an offset of the measured monthly air temperature. The model does not simulate the physical movement of water through soil, but rather treats the soil as a reservoir with fixed available water 
Figure 1. Soil moisture and temperature regimes for Chile (adapted from NRCS, 2016a).

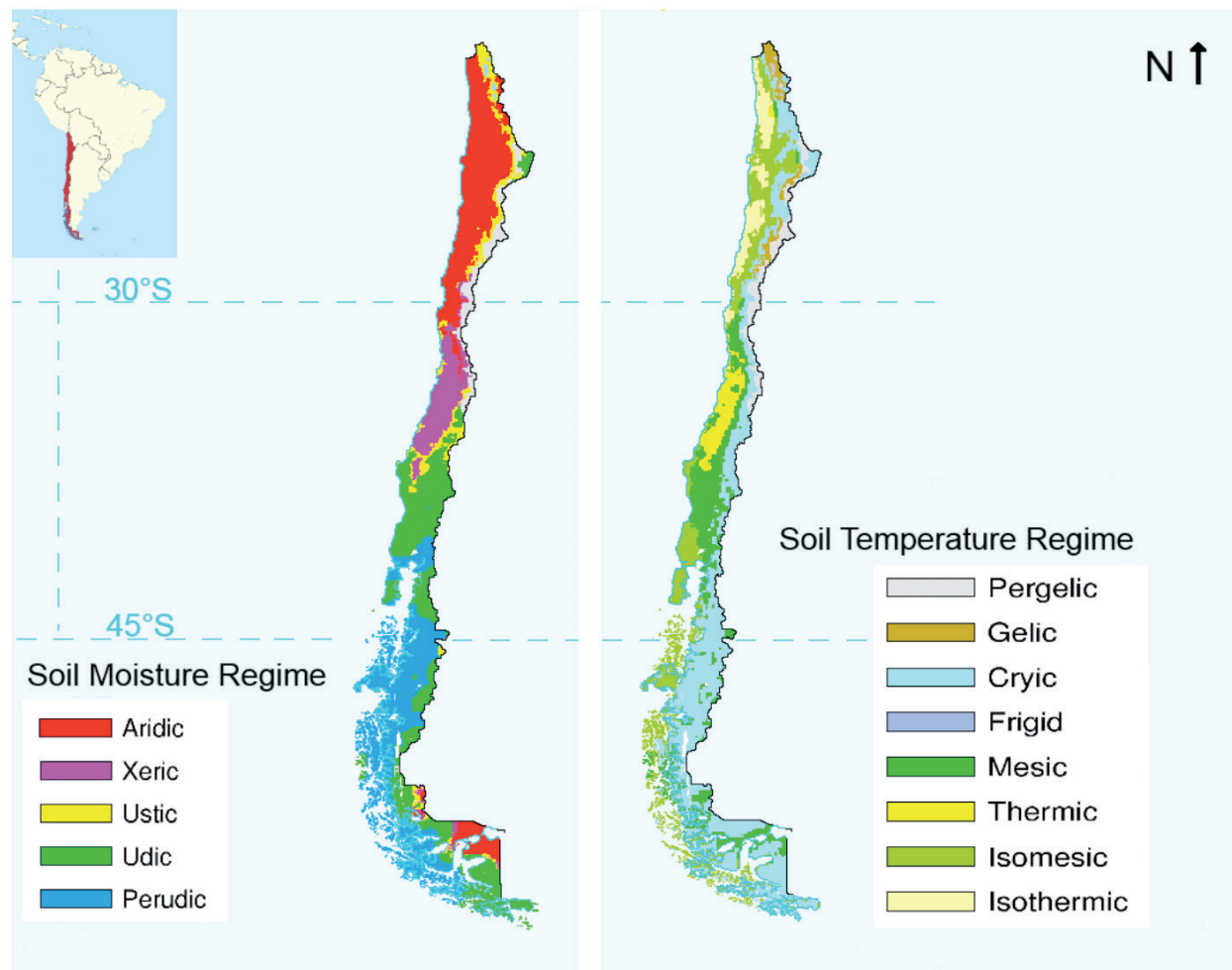

capacity (AWC) that is initially set to $200 \mathrm{~mm}$, but may be modified by the user according to soil properties. The soil is conceptually represented by an $8 \times 8$ matrix profile, with the second and third rows corresponding to the SMCS. Soil water from precipitation enters the matrix horizontally from the top, and is depleted through diagonal slants in the matrix. The precipitation amount that exceeds water storage capacity is lost by runoff or by deep percolation, and the loss of stored water is through evapotranspiration (Van Wambeke and Luzio, 1981; Newhall and Berdanier, 1996). The model runs on a monthly time-step sequence to process the climate data (monthly precipitation and mean temperature), and the moisture status in the control section and temperature at the defined depth are registered accordingly. The time-series of soil moisture (number of days moist, partially moist or dry) and temperature status (number of days $\geq 5{ }^{\circ} \mathrm{C}$ or $\geq 8{ }^{\circ} \mathrm{C}$ ) are then characterized in the model output according to the defined characteristics of the SMR and STR (NRCS, 2016b). The model further subdivides the SMR classes into proposed subgroups (Van Wambeke, 1981) which presently have not been formally incorporated into Soil Taxonomy. The Newhall model essentially produces a mesoscale approximation of soil climate in the area of meteorological stations that is applicable to soil survey and maps of soil climate regimes (Winzeler et al., 2013). The model has also been used in investigations related to the effects of weather on crops (Jeutong et al., 2000; Yamoah et al., 2003) and impacts of climate change on soil moisture (Topete et al., 2014).

Therefore, considering that Chile is a country with diverse and variable climatic conditions that influence agricultural and forestry activities, the objective of this research was to test the hypothesis that long term climate change, from the early Twentieth Century to the present, may have changed the predominant SMRs and STRs at different locations in Chile.

\section{MATERIALS AND METHODS}

Long-term historical data from meteorological stations was obtained from the Annual Weather Summary Reports of Chile which are available from the National Meteorological Center of Chile (DMC, 2016) and the National Climatic Data Center of the National Oceanic and Atmospheric Administration (NOAA, 2016). The Annual reports included monthly weather data, such as cumulative precipitation and mean temperature values, (no daily measurements) from meteorological stations that are geographically distributed throughout the country. The weather data for some stations dates back to 1871 , but since the general format of the data before 1912 was not uniform with later observations, the maximum time span for this study was approximately $100 \mathrm{yr}$ before present (2015). Additionally, over time, meteorological measurements were discontinued in some localities and initiated in others. The weather stations that were selected for this study were therefore the ones that included relatively continuous measurements from the past towards the present, representing time spans of at least 50 to $100 \mathrm{yr}$, approximately, depending on the station. The weather station sites that were included in this investigation are listed in geographical order (northern to southern Chile) in Table 1. 
Table 1. Characteristics of the meteorological stations in Chile, including time span (years) of weather data, latitude, longitude and elevations above sea level. The stations are listed in geographical order, from north to south.

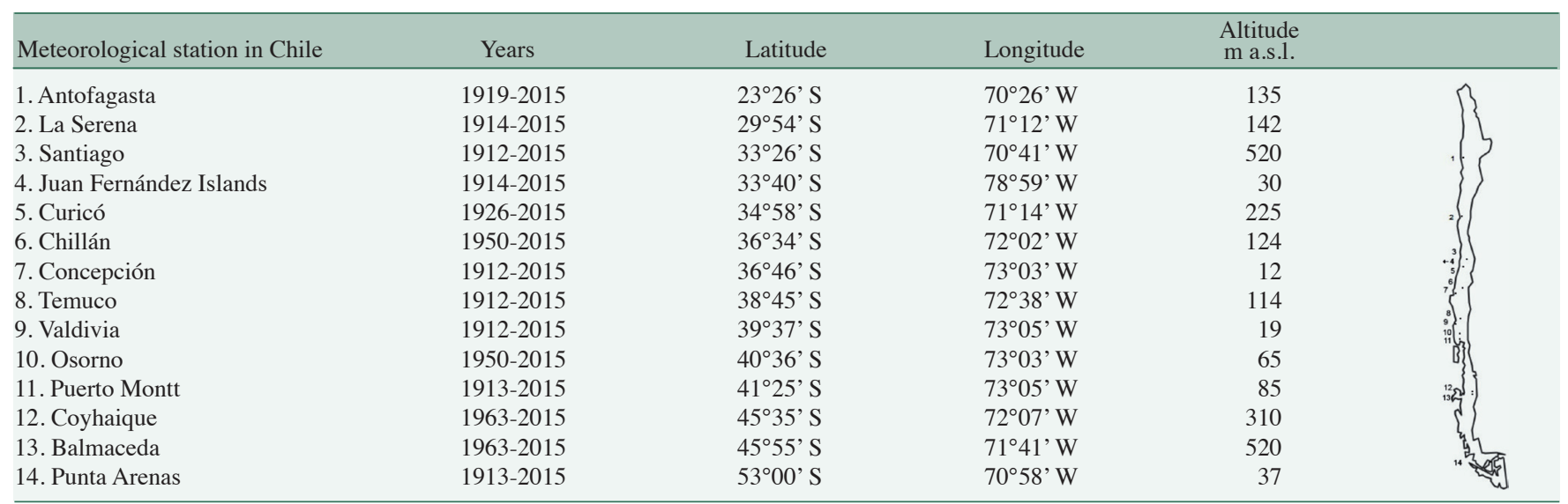

Historical values of monthly precipitation and mean temperature were input to the Java Newhall Simulation Model (jNSM), version 1.6.1 (NRCS, 2016b) as follows: The monthly data for complete years from each station was saved to comma separated values (csv) files, with metric units, in format compatible with the model. The offset of air temperature to soil temperature was set to $2{ }^{\circ} \mathrm{C}$, and the soil available water was set to $180 \mathrm{~mm}$, based on historical data from the Santiago station (DMC, 2016) and the dominant characteristics (texture and water retention) of the major soils of Chile (CIREN, 1996a; 1996b; 1997a; 1997b; 1999; 2002; 2003; 2005a; 2005b; 2007) which are most commonly of volcanic origin with silt loam to fine sandy loam textures (Luzio et al., 2010). Simulations were then carried out in batch runs.
The model output included Soil Temperature Regime (STR), Soil Moisture Regime (SMR) and subgroup (Table 2), number of days when the soil temperature is $\geq 5^{\circ} \mathrm{C}$ and the soil moisture control section (SMCS) is moist (bio5mm), dry (bio5dd) or partially moist and dry (bio5md). The model output parameters of STR, SMR and subclass and bio5mm for the meteorological stations were compared between pre-1985 and 1985-2015 in order to determine the most common regime classes and mean bio5mm days in each period. A normal year for each station was determined using the pre-1985 data to calculate the mean annual temperature and precipitation \pm one standard deviation, and the percent outlier years that were not normal for the periods pre1985 and 1985-2015 was then calculated for each station. Linear regression was used to assess the general trends

Table 2. Summary of Soil Moisture Regimes (SMR) and subgroups, and Soil Temperature Regimes (STR) as determined using the Newhall model that are used to classify soils in Soil Taxonomy (Van Wambecke, 1981; Soil Survey Staff, 2014).

\begin{tabular}{|c|c|}
\hline SMR and subgroups & Summary of characteristics in soil moisture control section \\
\hline Aquic & Saturated with water and virtually free of dissolved oxygen \\
\hline Aridic & Generally hot and dry conditions \\
\hline Weak Aridic & Moist or partially moist $>45$ but $<90$ consecutive days when soil temperature $>8^{\circ} \mathrm{C}$ \\
\hline Typic Aridic & Moist or partially moist $\leq 45$ consecutive days when soil temperature $>8^{\circ} \mathrm{C}$ \\
\hline Extreme Aridic & Completely dry during the whole year \\
\hline Ustic & Moisture is generally limited but present during growing season \\
\hline Wet Tempustic & Moist in all parts $>45$ consecutive days in winter and not dry $\geq 45$ consecutive days in summer \\
\hline Typic Tempustic & Dry or partially dry $\geq 90$ cumulative days and not dry in all parts $>$ half cumulative days when soil temperature $>5^{\circ} \mathrm{C}$ \\
\hline Xeric Tempustic & Xeric SMR but has a mean annual soil temperature (MAST) $\geq 22^{\circ} \mathrm{C}$ \\
\hline Udic & Moisture is generally not limited and is available throughout the growing season \\
\hline Typic Udic & Dry in some or all parts $<30$ cumulative days \\
\hline Dry Tempudic & Dry in some or all parts $\geq 30$ cumulative days \\
\hline Perudic & Always moist and precipitation exceeds evapotranspiration in all months \\
\hline Xeric & Generally moist in winter and dry in summer \\
\hline Typic Xeric & Dry in all parts 45 to $\leq 90$ consecutive days in summer \\
\hline Dry Xeric & Dry in all parts $>90$ consecutive days in summer \\
\hline STR $^{1}$ & Mean Annual Soil Temperature (MAST) at $50 \mathrm{~cm}$ depth \\
\hline Cryic & MAST is $0-8^{\circ} \mathrm{C}$ \\
\hline Frigid & MAST is similar to Cryic but with warmer summer soil temperatures \\
\hline Mesic & MAST is $8-15^{\circ} \mathrm{C}$ \\
\hline Thermic & MAST is $15-22^{\circ} \mathrm{C}$ \\
\hline Hyperthermic & MAST is $>22^{\circ} \mathrm{C}$ \\
\hline
\end{tabular}

\footnotetext{
${ }^{1}$ A prefix "iso" is used with the aforementioned temperature classes when the mean summer and winter soil temperatures differ by $<6{ }^{\circ} \mathrm{C}$.
} 
of temperature and precipitation over time, and T-tests were used to compare between periods the mean annual temperature and precipitation and the bio5mm output for the meteorological stations (Di Rienzo et al., 2012).

\section{RESULTS AND DISCUSSION}

The Soil Temperature Regime (STR) based on the historical (pre-1985) mean monthly temperatures from the meteorological stations was Isothermic in northern Chile along the coast and Thermic in inland areas, as expected (Table 3), and further south the STR was Isomesic and Mesic in coastal and inland areas, respectively. The Soil Moisture Regime (SMR), based on the historical (pre-1985) mean monthly precipitation, generally trended from north at Antofagasta to south at Puerto Montt as Aridic, Xeric, Ustic, Udic and Perudic; and were drier further south and inland. The dominant SMR subgroup was Extreme Aridic in the north and Dry Xeric, Typic Xeric, Udic Tropustic and Typic Udic further south (the Perudic SMR does not have a subgroup). The trends of STR and SMR were closely related to mean annual temperature which decreased, and mean annual precipitation which generally increased, from northern to southern Chile (Table 3), with the exceptions being areas that are strongly influenced by local physiographic conditions, as previously stated. The pre1985 STR and SMR classifications for the weather stations were generally similar to those reported in an earlier study (Van Wambeke and Luzio, 1981).

The linear regressions of mean annual temperature $\left({ }^{\circ} \mathrm{C}\right)$ $v s$. time (yr) for the historical meteorological data until 2015 were significant $(\mathrm{P}<0.05)$ for the stations of La Serena, Santiago, Curicó, Concepción, Temuco, Valdivia, Puerto Montt and Punta Arenas (Table 4). The annual temperature generally decreased over time, by $-0.0120{ }^{\circ} \mathrm{C} \mathrm{yr}^{-1}$, on average. In Santiago, however, the annual temperature

Table 3. Soil temperature regime (STR), soil moisture regime (SMR), and subgroup, as determined using the Newhall model (based on the pre-1985 weather data) and mean monthly temperature and precipitation at meteorological stations in Chile.

\begin{tabular}{|c|c|c|c|c|c|}
\hline \multirow[b]{2}{*}{ Meteorological station in Chile } & \multirow[b]{2}{*}{ STR } & \multirow[b]{2}{*}{ SMR } & \multirow[b]{2}{*}{ SMR subgroup } & \multicolumn{2}{|c|}{ Mean } \\
\hline & & & & Temperature & Precipitation \\
\hline & & & & ${ }^{\circ} \mathrm{C}$ & $\mathrm{mm}$ \\
\hline 1. Antofagasta & Isothermic & Aridic & Extreme Aridic & 16.5 & 4.4 \\
\hline 2. La Serena & Isothermic & Aridic & Extreme Aridic & 14.0 & 96.3 \\
\hline 3. Santiago & Thermic & Xeric & Dry Xeric & 14.4 & 327.5 \\
\hline 4. Juan Fernández Islands & Isothermic & Ustic & Udic Tropustic & 15.1 & 1003.0 \\
\hline 5. Curicó & Thermic & Xeric & Dry Xeric & 13.6 & 733.0 \\
\hline 6. Chillán & Mesic & Xeric & Typic Xeric & 12.9 & 1067.2 \\
\hline 7. Concepción & Isomesic & Ustic & Udic Tropustic & 12.5 & 1160.8 \\
\hline 8. Temuco & Mesic & Udic & Typic Udic & 11.6 & 1241.0 \\
\hline 9. Valdivia & Mesic & Udic & Typic Udic & 11.6 & 2162.7 \\
\hline 10. Osorno & Mesic & Udic & Typic Udic & 10.6 & 1321.2 \\
\hline 11. Puerto Montt & Isomesic & Perudic & none & 10.5 & 1800.0 \\
\hline 12. Coyhaique & Mesic & Udic & Typic Udic & 8.2 & 1166.9 \\
\hline 13. Balmaceda & Mesic & Xeric & Typic Xeric & 6.3 & 574.4 \\
\hline 14. Punta Arenas & Mesic & Aridic & Weak Aridic & 6.3 & 406.8 \\
\hline
\end{tabular}

Table 4. Parameters of linear regression for mean annual temperature and precipitation versus time of meteorological stations in Chile, from historical weather data until 2015.

\begin{tabular}{|c|c|c|c|c|c|c|}
\hline \multirow[b]{3}{*}{ Meteorological station in Chile } & \multicolumn{6}{|c|}{ Linear regression } \\
\hline & \multicolumn{3}{|c|}{ Temperature $=\mathrm{m} \times$ Year + Intercept } & \multicolumn{3}{|c|}{ Precipitation $=\mathrm{m} \times$ Year + Intercept } \\
\hline & Slope & Intercept & $\mathrm{R}^{2}$ & Slope & Intercept & $\mathrm{R}^{2}$ \\
\hline & ${ }^{\circ} \mathrm{C} \mathrm{yr} r^{-1}$ & $\mathrm{~m}$ & & $\mathrm{~mm} \mathrm{yr}^{-1}$ & $\mathrm{~m}$ & \\
\hline 1. Antofagasta & 0.0004 & 15.8 & 0.000 & -0.05 & 104 & 0.027 \\
\hline 2. La Serena & -0.0173 & 48.0 & $0.302 *$ & -0.60 & 1270 & $0.067 *$ \\
\hline 3. Santiago & 0.0087 & -2.7 & $0.326^{*}$ & -0.84 & 1970 & 0.029 \\
\hline 4. Juan Fernández Islands & 0.0031 & 9.1 & 0.020 & 0.24 & 528 & 0.001 \\
\hline 5. Curicó & -0.0127 & 38.7 & $0.242 *$ & -3.02 & 6684 & $0.084 *$ \\
\hline 6. Chillán & 0.0007 & 11.6 & 0.001 & -2.09 & 5206 & 0.023 \\
\hline 7. Concepción & -0.0090 & 30.1 & $0.118^{*}$ & -3.84 & 8731 & $0.142 *$ \\
\hline 8. Temuco & -0.0104 & 32.0 & $0.321 *$ & -3.11 & 7362 & $0.155^{*}$ \\
\hline 9. Valdivia & -0.0091 & 29.4 & $0.291 *$ & -9.85 & 21466 & $0.323 *$ \\
\hline 10. Osorno & 0.0046 & 1.4 & 0.050 & -5.44 & 12099 & $0.178 *$ \\
\hline 11. Puerto Montt & -0.0166 & 43.2 & $0.437 *$ & -5.45 & 12526 & $0.194 *$ \\
\hline 12. Coyhaique & 0.0004 & 7.4 & 0.000 & -16.93 & 34892 & $0.305^{*}$ \\
\hline 13. Balmaceda & 0.0044 & -2.3 & 0.020 & -3.42 & 7371 & $0.163 *$ \\
\hline 14. Punta Arenas & -0.0087 & 23.3 & $0.150 *$ & -0.54 & 1470 & 0.021 \\
\hline
\end{tabular}

*Linear regression model is significant $(\mathrm{P}<0.05)$. 
increased by $0.0087^{\circ} \mathrm{C} \mathrm{yr}^{-1}$. The linear regressions of annual precipitation $(\mathrm{mm}) v s$. time (yr) for the historical data until 2015 were significant for La Serena, Curicó, Concepción, Temuco, Valdivia, Osorno, Puerto Montt, Coyhaique and Balmaceda. In general, the annual precipitation decreased by greater increments proceeding from north to south. For example, the rate of decrease was $-0.60 \mathrm{~mm} \mathrm{yr}^{-1}$ for la Serena in the north, $-3.32 \mathrm{~mm} \mathrm{yr}^{-1}$ (mean) for south central Chile (Curicó, Concepción and Temuco), -9.85 $\mathrm{mm} \mathrm{yr}^{-1}$ in Valdivia, and $-5.45 \mathrm{~mm} \mathrm{yr}^{-1}$ (mean) in Osorno and Puerto Montt. The decrease rates for Coyhaique and Balmaceda were -16.93 and $-3.42 \mathrm{~mm} \mathrm{yr}^{-1}$, respectively. The regressions for the meteorological records of shorter length (Chillán, Osorno, Coyhaique and Balmaceda) are not directly comparable to those of longer length (Table 1) but the trends are generally consistent between the two groups of stations.

Comparison of the mean annual temperature between the periods showed that in several areas the mean annual temperature before 1985 was similar to the period of 1985 to 2015 , but in others the temperatures were slightly cooler $(\mathrm{P}<0.05)$ in the latter period and included the stations of La Serena in the north, Temuco, Valdivia, Puerto Montt in south central Chile, and Punta Arenas further south (Table 5). This was similar to the reported temperature trends in the recent Intergovernmental Panel on Climate Change (IPCC) report (Magrin et al., 2014). However, Santiago, which is the largest city of Chile with approximately seven million inhabitants, was the only area that registered an increase of temperature between periods which was possibly due to anthropogenic factors such as increased urbanization and atmospheric contamination in the central valley basin (Mena-Carrasco et al., 2014). Nevertheless, the dominant STRs of pre-1985 (Table 3) did not change in the 19852015 period among the aforementioned locations.

The mean annual precipitation for 1985 to 2015 was generally lower $(\mathrm{P}<0.05)$ than the period prior to 1985 for stations in central to southern Chile that included Curicó,
Concepción, Temuco, Valdivia, Osorno, Puerto Montt and Coyhaique (Table 5). The percent decrease in mean annual precipitation between periods was $24 \%$ in Curicó, $16 \%$ in Concepción, $13 \%$ in Temuco, 22\% in Valdivia, $13 \%$ in Osorno, $17 \%$ in Puerto Montt and 31\% In Coyhaique. The decreased precipitation in south central Chile was similar to the reported trends in the recent IPCC report (Magrin et al., 2014). However, the dominant SMRs in the 19852015 period were generally similar to the pre-1985 SMRs (Table 3), except in Puerto Montt where the SMR pre-1985 was Perudic (no SMR subgroup) and 1985-2015 was UdicTypic Udic; and Punta Arenas, where the SMR pre-1985 was Aridic-Typic Aridic, and 1985-2015 was Xeric-Typic Xeric which was influenced by more favorable distribution of the rains and lower temperatures in the latter period. In Concepción, only the SMR subgroup within the Ustic SMR changed between periods from Ustic-Udic Tropustic to Ustic-Typic Tropustic. The subgroup classifications of SMR (Van Wambecke, 1981) are therefore useful to characterize small changes within a given SMR in response to decreasing precipitation in an area, such as Concepción.

The relative stability of the STRs and SMRs between pre-1985 and 1985-2015 periods did not reflect the changes that occurred in the frequency of outlier years with extreme temperatures or precipitation, that are not considered as normal years. This is illustrated in the long term temperature trends of Santiago, where the STR in both earlier and latter periods was Thermic, even though there was an increase $(\mathrm{P}<0.05)$ in the mean annual temperature from 14.3 to $14.8{ }^{\circ} \mathrm{C}$ (Table 5). Using the pre1985 mean annual temperature \pm one standard deviation as a normal year, it was found that in the 1985-2015 period there was a greater tendency for extreme warm years and a lower tendency for extreme cool years (Figure 2). In the latter period extreme warm years occurred $68 \%$ of the time compared to only $25 \%$ in the earlier period (Table 6), whereas extreme cool years occurred only $3 \%$ of the time in the latter period compared to $21 \%$ in the earlier period. The

Table 5. Mean annual temperature and precipitation before 1985 and 1985 to 2015 using historical weather data from Chilean meteorological stations.

\begin{tabular}{|c|c|c|c|c|}
\hline \multirow[b]{3}{*}{ Meteorological station in Chile } & \multicolumn{4}{|c|}{ Mean (standard deviation) } \\
\hline & \multicolumn{2}{|c|}{ Temperature } & \multicolumn{2}{|c|}{ Precipitation } \\
\hline & Before 1985 & 1985 to 2015 & Before 1985 & 1985 to 2015 \\
\hline & 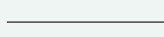 & - & & \\
\hline 1. Antofagasta & $16.4 \mathrm{~A}(0.5)$ & $16.6 \mathrm{~A}(0.5)$ & $4.8 \mathrm{~A}(9.3)$ & 3.7A (7.4) \\
\hline 2. La Serena & $14.2 \mathrm{~A}(1.0)$ & $13.7 \mathrm{~B}(0.5)$ & $105.4 \mathrm{~A}(66.3)$ & $81.3 \mathrm{~A}(57.6)$ \\
\hline 3. Santiago & $14.3 \mathrm{~A}(0.4)$ & $14.8 \mathrm{~B}(0.3)$ & 336.9A (142.4) & $305.5 \mathrm{~A}(156.9)$ \\
\hline 4. Juan Fernandez Islands & $15.1 \mathrm{~A}(0.8)$ & $15.2 \mathrm{~A}(0.3)$ & $1005.0 \mathrm{~A}(230.3)$ & 999.1A (192.9) \\
\hline 5. Curicó & $13.7 \mathrm{~A}(0.8)$ & $13.5 \mathrm{~A}(0.3)$ & 794.2A (269.1) & 604.8B (231.7) \\
\hline 6. Chillán & $12.8 \mathrm{~A}(0.5)$ & $13.0 \mathrm{~A}(0.4)$ & $1111.9 \mathrm{~A}(275.9)$ & $1017.5 \mathrm{~A}(252.6)$ \\
\hline 7. Concepción & $12.5 \mathrm{~A}(0.6)$ & $12.3 \mathrm{~A}(0.8)$ & $1233.7 \mathrm{~A}(253.2)$ & 1039.6B (270.8) \\
\hline 8. Temuco & $11.7 \mathrm{~A}(0.6)$ & $11.2 \mathrm{~B}(0.3)$ & $1298.6 \mathrm{~A}(231.7)$ & 1130.0B (233.2) \\
\hline 9. Valdivia & $11.7 \mathrm{~A}(0.5)$ & $11.2 \mathrm{~B}(0.4)$ & $2307.5 \mathrm{~A}(486.7)$ & $1805.0 \mathrm{~B}(454.0)$ \\
\hline 10. Osorno & $10.5 \mathrm{~A}(0.4)$ & $10.6 \mathrm{~A}(0.3)$ & $1406.5 \mathrm{~A}(182.3)$ & $1229.8 \mathrm{~B}(213.2)$ \\
\hline 11. Puerto Montt & $10.8 \mathrm{~A}(0.7)$ & $10.0 \mathrm{~B}(0.3)$ & $1905.1 \mathrm{~A}(358.2)$ & $1588.3 \mathrm{~B}(260.3)$ \\
\hline 12. Coyhaique & $8.3 \mathrm{~A}(0.4)$ & $8.2 \mathrm{~A}(0.5)$ & $1485.0 \mathrm{~A}(734.9)$ & 1022.7B (151.6) \\
\hline 13. Balmaceda & $6.3 \mathrm{~A}(0.5)$ & $6.4 \mathrm{~A}(0.5)$ & 609.4A (163.9) & 548.4A (95.8) \\
\hline 14. Punta Arenas & $6.4 \mathrm{~A}(0.8)$ & $6.1 \mathrm{~B}(0.4)$ & 407.7A (124.3) & $404.4 \mathrm{~A}(79.3$ \\
\hline
\end{tabular}

Different letters within a row indicate significant difference $(\mathrm{P}<0.05)$ of temperature or precipitation. 
Figure 2. Mean annual temperature of Santiago, Chile, between 1912 and 2015, and linear regression of temperature versus year ( $R^{2}$ $=0.326$ ).

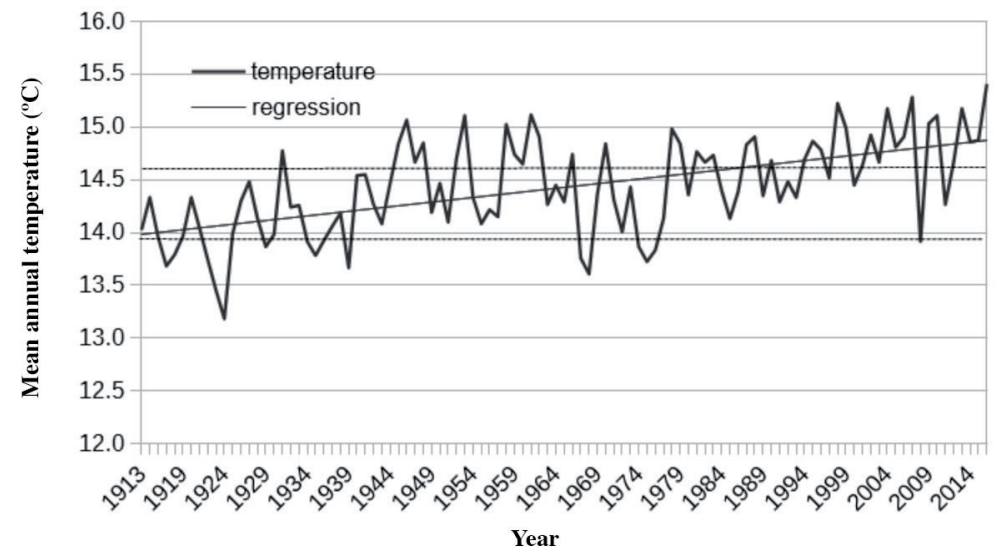

The dotted lines represent upper and lower limits ( \pm one standard deviation) of mean annual temperature, the range of a normal year for the pre-1985 period.

Table 6. Percent frequency of outlier years with not normal temperature or precipitation during the periods of pre-1985 and 1985 to 2015, at meteorological stations in Chile (a normal year is the pre-1985 mean \pm one standard deviation).

\begin{tabular}{|c|c|c|c|c|c|c|c|c|}
\hline \multirow{4}{*}{$\begin{array}{l}\text { Meteorological station in Chile } \\
\text { 1. Antofagasta }\end{array}$} & \multicolumn{8}{|c|}{ Frequency of years with not normal weather (percentage outlier years during period) } \\
\hline & \multicolumn{4}{|c|}{ Mean annual temperature } & \multicolumn{4}{|c|}{ Mean annual precipitation } \\
\hline & \multicolumn{2}{|c|}{ Before 1985} & \multicolumn{2}{|c|}{1985 to 2015} & \multicolumn{2}{|c|}{ Before 1985} & \multicolumn{2}{|c|}{1985 to 2015} \\
\hline & $-23^{1}$ & $+15^{2}$ & -3 & +13 & $-0^{3}$ & $+11^{4}$ & -0 & +7 \\
\hline 2. La Serena & -10 & +12 & -13 & +0 & -14 & +20 & -33 & +13 \\
\hline 3. Santiago & -21 & +25 & -3 & +68 & -15 & +14 & -26 & +6 \\
\hline 4. Juan Fernández Islands & -10 & +8 & -0 & +0 & -13 & +10 & -10 & +13 \\
\hline 5. Curicó & -23 & +15 & -5 & +0 & -19 & +17 & -36 & +0 \\
\hline 6. Chillán & -22 & +22 & -0 & +39 & -13 & +16 & -18 & +7 \\
\hline 7. Concepción & -16 & +16 & -10 & +3 & -18 & +19 & -48 & +3 \\
\hline 8. Temuco & -18 & +19 & -35 & +0 & -19 & +14 & -45 & +0 \\
\hline 9. Valdivia & -16 & +16 & -52 & +0 & -18 & +20 & -60 & +0 \\
\hline 10. Osorno & -13 & +22 & -5 & +29 & -22 & +17 & -38 & +5 \\
\hline 11. Puerto Montt & -20 & +22 & -68 & +0 & -11 & +13 & -42 & +0 \\
\hline 12. Coyhaique & -21 & +14 & -0 & +3 & -14 & +7 & -10 & +23 \\
\hline 13. Balmaceda & -23 & +18 & -20 & +20 & -14 & +23 & -13 & +0 \\
\hline 14. Punta Arenas & -11 & +2 & -16 & +3 & -16 & +20 & -3 & +6 \\
\hline
\end{tabular}

${ }^{1}$ Percentage of years with below normal temperatures.

${ }^{2}$ Percentage of years with above normal temperatures.

${ }^{3}$ Percentage of years with below normal precipitation.

${ }^{4}$ Percentage of years with above normal precipitation.

linear regression of the long term mean annual temperature versus year $\left(R^{2}=0.326\right)$ showed a general increase in temperature and the regression point of temperature for year 2015 was well above the upper limit of a normal pre 1985 year (Figure 2, Table 4). Furthermore, although the extreme warm years were still characterized by the Thermic STR, the SMR subgroup of those years was usually Weak Aridic rather than Dry Xeric of the normal years. In the other areas with cooler tendencies in 1985-2015 than the pre-1985 period (Table 5), the latter period had 0\% extreme warm years in La Serena, Temuco, Valdivia and Puerto Montt, and more frequent years that were extremely cool than the earlier period (Table 6).

The variability of annual precipitation within an area having a given SMR is illustrated for Concepción, where the dominant SMR (Ustic) did not change between pre1985 and 1985-2015 periods, although the SMR subgroup changed from Udic Tropustic to Typic Tropustic, as previously stated. The latter period had $48 \%$ frequency of extreme dry years, compared to $18 \%$ in the earlier period (Table 6), and extreme heavy rainfall occurred 3\% of the years in the latter period, and 19\% in the earlier period. The linear regression of the long term precipitation versus year (Table 4) indicated a general decrease in rainfall $\left(R^{2}=0.142\right)$ with the regression point of precipitation for 2015 on the lower limit of a pre-1985 normal year (Figure 3 ). The extreme dry years had the SMR subgroup of Typic Tropustic and the normal years were usually Udic Tropustic. In general, the meteorological stations in central to south central Chile (Santiago to Puerto Montt) had more frequent extreme dry years in 1985-2015, compared to the pre-1985 period (Table 6).

The bio5mm output from the Newhall model combines both soil temperature and moisture and is useful for 
Figure 3. Annual precipitation of Concepción, Chile, between 1912 and 2015, and linear regression of precipitation versus year ( $\mathbf{R}^{2}$ $=0.142$ ).

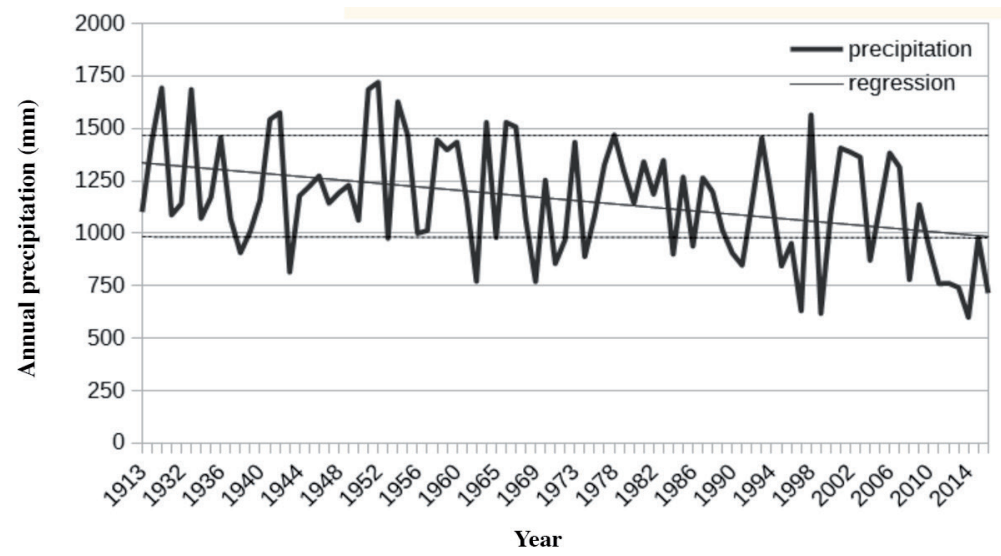

The dotted lines represent upper and lower limits ( \pm one standard deviation) of mean annual precipitation, the range of a normal year for the pre-1985 period.

estimating the number of days per year when there is available soil moisture and the soil temperature is at least $5{ }^{\circ} \mathrm{C}$, which is a "biological window" of plant and microbial activity (Waltman et al., 2011). Of the stations in central and south-central Chile with significant decreases of annual precipitation between the periods (Table 5), the bio5mm also decreased $(\mathrm{P}<0.05)$ between the periods (Figure 4$)$, and the mean decreases of the bio5mm parameter between periods were $23.2 \mathrm{~d}$ for Curicó, $10.0 \mathrm{~d}$ for Concepción, $17.3 \mathrm{~d}$ for Temuco, $17.2 \mathrm{~d}$ for Valdivia, $20.1 \mathrm{~d}$ for Osorno and $4.3 \mathrm{~d}$ for Puerto Montt. The general trend of fewer bio5mm days in the 1985-2015 period compared to the earlier period would mean fewer days with suitable soil conditions for crop growth, due to a combination of lower soil temperatures and available soil water. The tendency for drier soil conditions during the warmer months in central and south-central Chile, if continued, will likely result in a southerly expansion of the Xeric SMR into areas that currently have Udic SMR.

The results of the number of bio5mm days, pre-1985 and 1985-2015, suggested that the Newhall model could be used to identify specific areas in Chile where changing climatic conditions may by putting agricultural activities at risk, even when the SMR or STR may not necessarily have changed. The developing trends of soil moisture and temperature in central and south-central Chile may eventually require the adoption of more appropriate agricultural systems with increased irrigation, or geographic shifts of production to areas that are more suitable for a particular crop based on the prevalent climatic conditions. Nevertheless, it is important to periodically revise the SMR and STR classes of soils in Chile in order to have soil classifications that properly reflect the current climatic setting of soils used for crop, fruit, and grape or forest production.

\section{CONCLUSIONS}

Chile is a climatically diverse country with agriculture and forest production that is potentially susceptible to changes in temperature and rainfall regimes. Analysis of the historical weather records showed that in areas of central to southern Chile the mean annual temperature has decreased along the

Figure 4. Mean number of days per year with moist soil when the soil temperature is $\geq 5^{\circ} \mathrm{C}$ (bio5mm parameter), in the periods of pre-1985 and 1985-2015 for the meteorological stations of Curicó, Concepción, Temuco, Valdivia, Osorno, and Puerto Montt, in central and south-central Chile as calculated using the Newhall model.

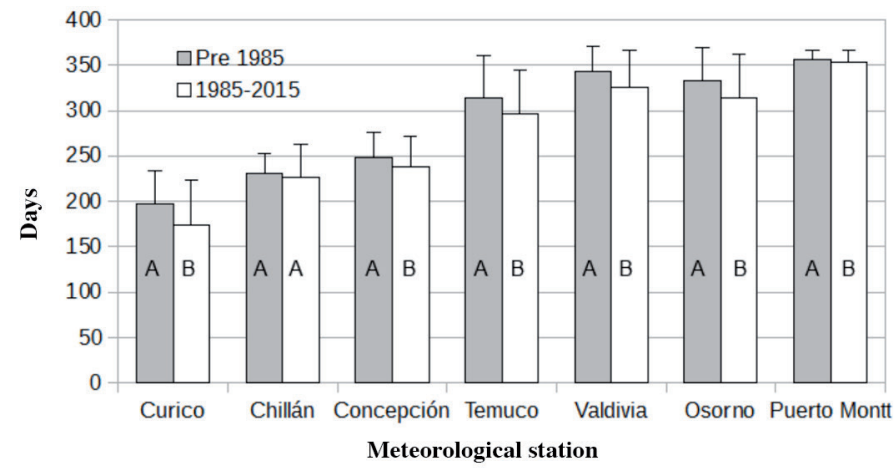

Columns with different letters are significantly different $(\mathrm{P}<0.05)$ 
coast, but the dominant Soil Temperature Regime (STR) of the locations has not changed between the pre-1985 and 1985 to 2015 periods. However, in Santiago, which is the biggest city of Chile, the mean annual temperature is higher in the latter period and probably is influenced by anthropogenic factors such as increased urbanization and atmospheric contamination. The results also showed that mean annual precipitation is decreasing in central and southcentral Chile, but the dominant Soil Moisture Regimes (SMRs) and subgroups are generally similar between periods, except in Puerto Montt where the SMR changed from Perudic to Udic-Typic Udic, and in Punta Arenas where it changed from Aridic-Typic Aridic to Xeric-Typic Xeric. In Concepcion only the SMR subgroup changed from Ustic-Udic Tropustic to Ustic-Typic Tropustic. In general, in central and south-central Chile, the latter period has greater occurrence of extreme years with lower temperatures and less precipitation, compared to the earlier period. The Newhall model calculations also indicated that in south-central Chile the 1985 to 2015 period had fewer annual days with moist soil when the soil temperature was at least $5{ }^{\circ} \mathrm{C}$, compared to the earlier period which suggests that soil conditions have become somewhat more limiting to crop and forest production. The tendency for drier soil conditions during the warmer months in central and southcentral Chile will likely result in an eventual southerly expansion of the Xeric SMR into areas that currently have Udic SMR, with increased climatic stresses for crops and forest production. Governmental programs therefore might have to increase technical and monetary support to those areas needing to adjust their current agriculture and forestry practices, and provide mechanisms for greater access to irrigation. Based on the results of this investigation, it is recommended to continue monitoring the trends of mean annual temperature and precipitation to determine when it may become necessary to revise the dominant STR, SMR and subgroups in the classifications of soils in Chile in order to reflect the actual climate related risks that may affect the agriculture and forestry sectors of the Chilean economy.

\section{REFERENCES}

Bockheim, J.G., A.N. Gennadiyev, A.E. Hartemink, and E.C. Brevik. 2014. Soil-forming factors and Soil Taxonomy. Geoderma 226:231-237.

Bonfante, A., A. Basile, P. Manna, and F. Terribile. 2011. Use of physically based models to evaluate USDA soil moisture classes. Soil Science Society of America Journal 75:181-191.

Buol, S.W., R.J. Southard, R.C. Graham, and P.A. McDaniel. 2011. Soil genesis and classification. $6^{\text {th }}$ ed. 544 p. John Wiley \& Sons, Chichester, UK.

Carey, J. 2016. News feature: Crucial role of belowground biodiversity. Proceedings of the National Academy of Sciences of the United States of America 113:7682-7685.

CIREN. 1996a. Estudio agrológico Región Metropolitana. Descripciones de suelos. Materiales y símbolos. Publicación CIREN N ${ }^{\circ} 115.464$ p. 2 v. Centro de Información de Recursos Naturales (CIREN), Santiago, Chile.
CIREN. 1996b. Estudio agrológico VI Región. Descripciones de suelos. Materiales y símbolos. Publicación CIREN N ${ }^{\circ} 114$ p. 570 p. 2 v. Centro de Información de Recursos Naturales (CIREN), Santiago, Chile.

CIREN. 1997a. Estudio agrológico V Región. Descripciones de suelos. Materiales y símbolos. Publicación CIREN N ${ }^{\circ} 116$ p. 392 p. 2 v. Centro de Información de Recursos Naturales (CIREN), Santiago, Chile.

CIREN. 1997b. Estudio agrológico VII Región. Descripciones de suelos. Materiales y símbolos. Publicación CIREN No 117.660 p. Centro de Información de Recursos Naturales (CIREN), Santiago, Chile.

CIREN. 1999. Estudio agrológico VIII Región. Descripciones de suelos. Materiales y símbolos. Publicación CIREN N ${ }^{\circ} 121$ p. 586 p. 2 vol. Centro de Información de Recursos Naturales (CIREN), Santiago, Chile.

CIREN. 2002. Estudio agrológico IX Región. Descripciones de suelos. Materiales y símbolos. Publicación CIREN N 122 p. 360 p. Centro de Información de Recursos Naturales (CIREN), Santiago, Chile.

CIREN. 2003. Estudio agrológico X Región. Descripciones de suelos. Materiales y símbolos. Publicación CIREN N 123 p. 412 p. 2 vol. Centro de Información de Recursos Naturales (CIREN), Santiago, Chile.

CIREN. 2005a. Estudio agrológico IV Región. Descripciones de suelos. Materiales y símbolos. Publicación CIREN N 129. 330 p. Centro de Información de Recursos Naturales (CIREN), Santiago, Chile.

CIREN. 2005b. Estudio agrológico XI Región. Descripciones de suelos. Materiales y símbolos. Publicación CIREN N 130 p. 126 p. Centro de Información de Recursos Naturales (CIREN), Santiago, Chile.

CIREN. 2007. Descripciones de suelos, Materiales y símbolos. Estudio Agrológico Valle del Copiapo y Valle del Huasco, III Región. Publicación CIREN N ${ }^{\circ} 135$ p. Centro de Información de Recursos Naturales (CIREN), Santiago, Chile.

Clements, R., J. Hagger, A. Quezada, and J. Torres. 2011. Technologies for climate change adaptation-agriculture sector. 198 p. In X. Zhu (ed.) United Nations Environment Programme (UNEP), Riso Centre on Energy, Climate and Sustainable Development, Roskilde, Denmark.

Davidson, E.A., and I.A. Janssens. 2006. Temperature sensitivity of soil carbon decomposition and feedbacks to climate. Nature 440:165-173.

Di Rienzo, J.A., F. Casanoves, M.G. Balzarini, L. Gonzalez, M. Tablada, y C.W. Robledo. 2012. InfoStat versión 2012. 302 p. InfoStat Group, Facultad de Ciencias Agropecuarias, Universidad Nacional de Córdoba, Argentina.

DMC. 2016. Climatología. Dirección Meteorológica de Chile (DMC), Dirección General de Aeronáutica Civil, República de Chile, Santiago, Chile. Available at http://www.meteochile.cl/ PortalDMC-web/index.xhtml (accessed 20 April 2016).

Dore, M. 2005. Climate change and changes in global precipitation patterns: What do we know? Environmental International 31:1167-1181.

Falvey, F., and R. Garreaud. 2009. Regional cooling in a warming world: Recent temperature trends in the southeast Pacific and along the west coast of subtropical South America (1979-2006). Journal of Geophysical Research 114:D04102. doi:10.1029/2008JD010519.

Hannah, L., P.R. Roehrdanz, M. Ikegami, A.V. Shepard, M.R. Shaw, G. Tabor, et al. 2013. Climate change, wine, and conservation. Proceeding of the National Academy of Sciences of the United States of America 110:6907-6912. 
Haylock, M.R., T.C. Peterson, L.M. Alves, T. Ambrizzi, M.T. Anunciacão, J. Baez, et al. 2006. Trends in total and extreme South American rainfall in 1960-2000 and links with sea surface temperature. Journal of Climate 19:1490-1512.

Jeutong, F., K.M. Eskridge, W.J. Waltman, and O.S. Smith. 2000. Comparison of bio climatic indices for prediction of maize yields. Crop Science 40:1612-1617.

Klausmeyer, K.R., and M.R. Shaw. 2009. Climate change, habitat loss, protected areas and the climate adaptation potential of species in Mediterranean ecosystems worldwide. PLoS ONE 4(7):e6392. doi:10.1371/journal.pone.0006392.

Luzio, W., M. Casanova, y O. Seguel. 2010. Suelos de Chile. 364 p. Universidad de Chile, Santiago, Chile.

Magrin, G.O., J.A. Marengo, J.-P. Boulanger, M.S. Buckeridge, E. Castellanos, G. Poveda, et al. 2014. Central and South America. p. 1499-1566. In Barros, V.R., C.B. Field, D.J. Dokken, M.D. Mastrandrea, K.J. Mach, T.E. Bilir, et al. (eds.) Climate Change 2014: Impacts, adaptation, and vulnerability. Part B: Regional Aspects. Contribution of Working Group II to the Fifth Assessment Report of the Intergovernmental Panel on Climate Change. Cambridge University Press, Cambridge, UK.

Mena-Carrasco, M., P. Saide, R. Delgado, P. Hernandez, S. Spak, L. Molina, et al. 2014. Regional climate feedbacks in central Chile and their effect on air quality episodes and meteorology. Urban Climate 10:771-781.

Minetti, J., W. Vargas, A. Poblete, L. Acuña, and G. Casagrande. 2003. Non-linear trends and low frequency oscillations in annual precipitation over Argentina and Chile, 1931-1999. Atmósfera 16:119-135.

MMA. 2013. Plan de adaptación al cambio climático del sector silvoagropecuario. 65 p. Ministerio del Medio Ambiente (MMA), Gobierno de Chile, Santiago, Chile.

Newhall, F., and C.R. Berdanier. 1996. Calculation of soil moisture regimes from the climate record. Soil Survey Investigative Report $N^{\circ} 46.15$ p. National Soil Survey Center, USDA, Lincoln, Nebraska, USA.

NOAA. 2016. Chile climatological data. National Oceanic and Atmospheric Administration (NOAA), Washington, DC., USA. Available at http://docs.lib.noaa.gov/rescue/data_rescue_chile. html (accessed 20 April 2016).

NRCS. 2016a. World soil resources map index. Natural Resources Conservation Service (NRCS), United States Department of Agriculture (USDA), Washington, DC., USA. Available at https://www.nrcs.usda.gov/wps/portal/nrcs/detail/soils/edu/ college/?cid=nrcs142p2_054010 (accessed 1 March 2016).

NRCS. 2016b. Java Newhall Simulation Model (jNSM) and User's Guide version 1.6.1. Natural Resources Conservation Service (NRCS), United States Department of Agriculture (USDA), Washington, DC. Available at https:/www.nrcs.usda.gov/wps/ portal/nrcs/detail/soils/survey/class/?cid=nrcs142p2_053559 (accessed 1 March 2016).
Quintana, J.M., and P. Aceituno. 2012. Changes in the rainfall regime along the extratropical west coast of South America (Chile) 30-43 S. Atmósfera 25:1-22.

Seneviratne, S., T. Corti, E. Davin, M. Hirschi, E. Jaeger, I. Lehner, et al. 2010. Investigating soil moisture-climate interactions in a changing climate: A review. Earth-Science Reviews 99:125-161.

Seo, S.N., and R. Mendelsohn. 2008. An analysis of crop choice: Adapting to climate change in South American farms. Ecological Economics 67:109-116.

Soil Survey Staff. 2014. Keys to soil taxonomy. $12^{\text {th }}$ ed. 372 p. Natural Resource Conservation Service, United States Department of Agriculture, Washington, DC., USA.

Topete, J.P., J.A. Ruiz, J. Ron, D.R. González, G. Ramírez, and N. Duran. 2014. Using the Newhall model to depict the impacts of climate change on soil moisture in Jalisco, Mexico. Revista Mexicana de Ciencias Agrícolas, Publicación Especial 10:1859-1870.

Van Wambeke, A. 1981. Calculated soil moisture and temperature regimes of South America: a compilation of soil climatic regimes calculated by using a mathematical model developed by F. Newhall. 168 p. New York State College of Agriculture and Life Sciences, Cornell University, Ithaca, New York, USA.

Van Wambeke, A., y W. Luzio. 1981. Determinación de los regímenes de humedad y temperatura para los suelos de Chile. Agricultura Técnica (Chile) 42:149-159.

Vera, C., G. Silvestri, B. Liebmann, and P. González. 2006. Climate change scenarios for seasonal precipitation in South America from IPCC-AR4 models. Geophysical Research Letters 33:L13707. doi:10.1029/2006GL025759.

Waltman, S.W., D.A. Miller, B. Bills, and W.J. Waltman. 2011. JAVA Newhall simulation model-Update to a traditional soil climate simulation model. Book of Abstracts, ASA, CSSA and SSSA International Annual Meeting, San Antonio, Texas. 1619 October 2011. American Society of Agronomy (ASA), Crop Science Society of America (CSSA) and Soil Science Society of America (SSSA), Madison, Wisconsin, USA.

Winzeler, H.E., P.R. Owens, S.W. Waltman, W.J. Waltman, Z. Libohova, and D. Beaudette. 2013. A methodology for examining changes in soil climate geography through time: U.S. soil moisture regimes for the period 1971-2000. Soil Science Society of America Journal 77:213-225.

Yamoah, C.F., A. Bationo, T.J. Wyatt, B. Shapiro, and S. Koala. 2003. Simulated weather variables effects on millet fertilized with phosphate rock sand in the Sahel. Nutrient Cycling in Agroecosystems 67:167-176.

Yañez, L., y D. Cohen. 2015. Balanza comercial de productos silvoagropecuarios. Avance mensual enero-diciembre 2014. 26 p. Oficina de Estudios y Políticas Agrarias (ODEPA), Ministerio de Agricultura, Santiago, Chile. 